\title{
Stimulating Business Activities Using Positional Strategy of Ergo- Iconic Values and Its Implication on SMEs Agility
}

\author{
Rulinawaty, Law, Social and Political Science, Universitas Terbuka, Indonesia, ruly@ecampus.ut.ac.id, orcid: \\ 0000-0001-9909-0146 \\ Andriyansah, Doctoral Program of Management Science, Universitas Terbuka, Indonesia, \\ andri@ecampus.ut.ac.id, orcid 0000-0002-4851-2617 \\ Lukman Samboteng, Public Administration, Polytechnic of STIA LAN Makassar, \\ lukmansamboteng@yahoo.co.id, ORCID 0000-0003-1593-2700 \\ Esa Nadia Mubariqah, Accounting Major, Universitas Terbuka, Indonesia, esa.mubariqah@gmail.com
}

\begin{abstract}
This paper aims to measure the ergo-iconic value that plays a role in influencing the business agility of SMEs, this variable is used because during a pandemic, environmental uncertainty and an increasingly competitive business environment. This study examines the agile perspective of SMESs that can apply the ergo-iconic value positioning strategy is a strategy that can be implemented by companies to increase sales, to be able to embrace consumers supported by two independent variables and the dependent variable and one variable that functions as a moderating variable, namely environment. external. This ergo-iconic service capability variable has the strength of 4 indicators and the dependent variable has 4 indicators. There are two hypotheses proposed in the study, namely the higher the positional ergo-iconic value, the higher the business agility and the higher the interaction of the external environment, the higher the business agility. This study concludes that business agility or agility is needed in a business situation which is indeed supported by the speed of technology companies. Real time information cannot be hindered by business ventures, so that the external environment in this paper will have an impact on agile business performance. Personal or organizational customers (employees) have an interest in the organization and have a stake in aligning it with organizational goals. Business agility or agility is indispensable in a business situation which is indeed supported by company speed, so that technology, especially real-time information, cannot be blocked by business ventures, so that the external environment in this paper will have an impact on agile business performance.
\end{abstract}

Keywords: Ergo-iconic Values, External Environment, Business Agility, Management Capability Received: 05.11.2020 $\quad$ Accepted: 13.12.2020 $\quad$ Published: 11.01.2021

\section{INTRODUCTION}

The beginning of 2020 has added new history in world civilization; all countries are focusing on how to resolve the COVID-19 pandemic. This focus affects many sectors become uncontrollable, which mostly are business sectors that have direct effect to livelihood. COVID-19 pandemic has forced countries to impose lockdown which restrain almost all economic sectors all over the world except populist business, which is the Micro, Small, and Medium Enterprises (SMEs). This sector is usually underestimated, while they provide several populist businesses which sustain people's economy. Populist economy becomes the new economic growth resources in the midst of pandemic. Based on Badan Pusat Statistik (Central Bureau of Statistics) in 2020, it was shown that there are 67,5 million of populist economic agents that should be boosted through digital economy in order to create positive performance for national economy. The empirical research of Ergo-Ikonic values mentioned that this variable could increase marketing performance, and besides that the service value can also increase its performance (Andriyansah et al., 2020).

Some countries in the world implemented several limitation rules and policies to give safety for their societies and decrease the death toll cases caused by Coronavirus Disease 2019 (COVID-19) spread. But in fact, these limitation policies became boomerang for them. It causes the weakening of economic strength and to world economy. The economic activity limitation policy caused disruption on supply chain, decrease production and public consumption, increase unemployment and failing small businesses. The writer assumed that there is situation and condition where ceteris paribus keep existed but based on business phenomenon during pandemic, the other factors beside demand and supply will also affect production process. 
The conjecture of economic power weakening can be solved with other variable with the assumption that this variable is not affected significantly to pandemic situation. The positional of ErgoIconic Values by Andriyansah (2018) which cited from marketing management science, stated that the applicative on this research will be done as the right strategy to raise millions of creative economy actors from informal sector to empower populist business such as SMEs. The next empiric shows that agile organization can be developed inside uncertain organization environment like pandemic situation (Rulinawaty, Samboteng, Arifin, \& Hasanuddin, 2020).

Strategy transformation is aimed for disturbed populist business growth by utilizing the positional strategy of ergo-iconic values; it is expected to increase the populist business performances. The right implementation of this strategy is needed, since SMEs have tendency to be slow in responding continuous and fast change in their environment and becomes agile business (Tiernan, 2015). The velocity of transformation is important to be executed in order to achieve development and continuity of organization both in public, private, civil society, and SMES business sectors (Rulinawaty, Arifin, et al., 2020).

A good comprehension of ergo-iconic can support SMEs in business agility development, but it has not been empirically proven that the variable is affecting positively or significantly to business growth(Andriyansah \& Fatimah, 2020). Business agility is private organization ability to sense and respond to unpredictable change in their internal and external organization environment (business opportunity) and conduct collaboration with policy makers according to Alwi \& Kasmad (2018), and to thrive together with other private organization in a completely competitive environment (Kasmad et al., 2019).

Business opportunity will be shown by taking competitive action in the midst of unpredictable environment, while taking into account that the criteria to establish SMES should actually make the SMES business an agile organization. This research will study on how the positional value of ergo-iconic can affect business agility for SMEs with competitive and uncertain environment.

The main thesis of this research is private organization (SMEs) which can use positional strategy of ergo-iconic value to activate four business agilities which are: strategizing agility, implementing agility, linking agility and people agility. While for unpredictable environment, it probably has a positive moderate effect for this research. First, the focus of this Ergo-iconic capability research is on four factors which are the flexibility conceptualization of the Iconic-Ergonomic Value, Iconic-Ergonomic Management, IconicErgonomic Technicalities, and Iconic-Ergonomic Talent which will make SMEs becomes an agile business. This research will explore on strategizing agility, implementing agility, linking agility, and people agility to create agile SMEs and external environment which is dynamic and complex.

\section{METHODS}

\section{Hypothesis Development}

Based on the above literature review, the hypothesis development on this paper are as follows: 1st Hypothesis: The higher the positional of ergo-iconic values, the business agility will be higher. 2nd Hypothesis: The higher the external environment interaction, the business agility will be higher.

The developed model on this paper is by using two variables which are independent variable that is the capability of ergo-iconic service and business agility variable which is the dependent variable. Empirical data has proved that business performance is not affected by both of the variables, so business environment variable is added in this model as moderator variable. Below is the model that was used on this research:

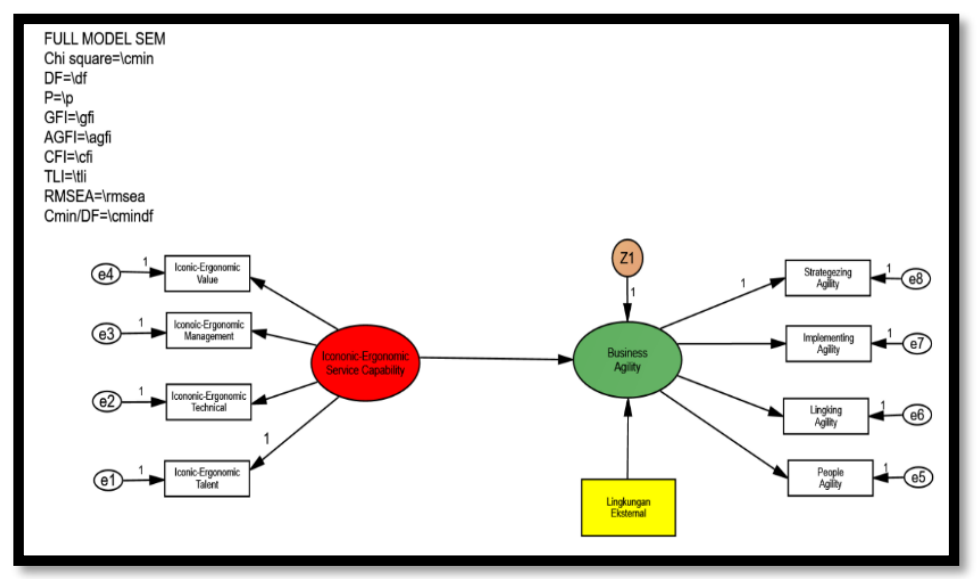

Figure 1. Develop Model Research 


\section{RESULTS}

It is the main section in which the collected data and findings are discussed. Cambria, 11 font, single line spacing, and first line indented $1 \mathrm{~cm}$, no space between paragraphs. It is the main section in which the collected data and findings are discussed. It is the main section in which the collected data and findings are discussed. Cambria, 11 font, single line spacing, and first line indented $1 \mathrm{~cm}$, no space between paragraphs. It is the main section in which the collected data and findings are discussed.

It is the main section in which the collected data and findings are discussed. Cambria, 11 font, single line spacing, and first line indented $1 \mathrm{~cm}$, no space between paragraphs. It is the main section in which the collected data and findings are discussed.

Tables should be inserted within the text. Captions should be placed above the table "Table X." bold. Name of the table should be in italic. APA style. No vertical lines in tables, 3 horizontal lines only. 10 pts within table.

\section{DISCUSSION AND CONCLUSIONS}

In a competitive business situation, we should be able to take a quick respond to do innovation. Business can develop a new strategy by creating new product or service, or even new additional value. Business agility is a must need in any business situation which is indeed supported by the speed of technology companies. The real-time information cannot be resisted by the businesses, due to that the external environment on this research will give effect to business agility performance.

\section{REFERENCES}

Adler, P. S., \& Borys, B. (1996). Two types of bureaucracy: Enabling and coercive. Administrative Science Quarterly, 41(1), 61-89. https://doi.org/10.2307/2393986

Alwi, \& Kasmad, R. (2018). Local collaborative network: Is it smart implementer of the cocoa business development policy in Indonesia? International Journal of Public Policy, 14(5-6), 374-390. https://doi.org/10.1504/IJPP.2018.096640

Andriyansah. (2018a). Keunggulan Posisional Nilai Produk Ergo-ikonik untuk Meningkatkan Kinerja Pemasaran. Diponegoro.

Andriyansah. (2018b). Positional Advantages of Ergo Product Value-Iconic To Improve Marketing Performances. http://eprints.undip.ac.id/63422/

Andriyansah, \& Fatimah, F. (2020). Developing the Concept of E-Customer Relationship Management Model to Improve Marketing Performance. International Conference on E-Commerce, E-Business and E-Government, 22-26. https://dl.acm.org/doi/proceedings/10.1145/3409929

Andriyansah, Fatimah, F., Hidayah, Z., \& Daud, A. (2020). Hotel dengan Memanfaatkan Nilai Pelayanan Ergoikonik. Jurnal Bisnis, Manajemen Dan Perbankan, 6(1), 63-68.

Belsky, J. M., Siebert, S. F., Argout, X., Salse, J., Aury, J.-M., Guiltinan, M. J., Droc, G., Gouzy, J., Allegre, M., Chaparro, C., Legavre, T., Maximova, S. N., Abrouk, M., Murat, F., Fouet, O., Poulain, J., Ruiz, M., Roguet, Y., Rodier-Goud, M., ... Acquaah, B. (2014). Report on Cacao Products. Cafe Cacao The. https://doi.org/BOOK_DOI 10.1201/b16546

Benitez, J., Llorens, J., \& Braojos, J. (2018). How information technology influences opportunity exploration and exploitation firm's capabilities. Information and Management, 55(4), 508-523. https://doi.org/10.1016/j.im.2018.03.001

Carvalho, A. M., Sampaio, P., Rebentisch, E., Carvalho, J. Á., \& Saraiva, P. (2019). Operational excellence, organisational culture and agility: the missing link? Total Quality Management and Business Excellence, 30(13-14), 1495-1514. https://doi.org/10.1080/14783363.2017.1374833

Chakravarty, A., Grewal, R., \& Sambamurthy, V. (2013). Information technology competencies, organizational agility, and firm performance: Enabling and facilitating roles. Information Systems Research, 24(4), 976-997. https://doi.org/10.1287/isre.2013.0500

Cheese, P. (2016). Managing risk and building resilient organisations in a riskier world. Journal of Organizational Effectiveness, 3(3), 323-331. https://doi.org/10.1108/JOEPP-07-2016-0044

Chen, Y., Wang, Y., Nevo, S., Benitez-amado, J., \& Kou, G. (2015). Information \& Management IT capabilities and product innovation performance: The roles of corporate entrepreneurship and competitive intensity. Information \& Management, 52(6), 643-657. https://doi.org/10.1016/j.im.2015.05.003

Chen, Y., Wang, Y., Nevo, S., Jin, J., Wang, L., \& Chow, W. S. (2014). IT capability and organizational performance: The roles of business process agility and environmental factors. European Journal of Information Systems, 23(3), 326-342. https://doi.org/10.1057/ejis.2013.4 
Grewal, R., \& Tansuhaj, P. (2001). Building Organizational Capabilities for Managing Economic Crisis: The Role of Market Orientation and Strategic Flexibility. Journal of Marketing, Kotha, 67-80. https://doi.org/https://doi.org/10.1509\%2Fjmkg.65.2.67.18259

Kasmad, R., \& Alwi, A. (2015). Democratic Model of Public Policy Accountability. Case Study on Implementation of Street Vendors Empowerment Policy in Makassar City. Jurnal Studi Pemerintahan, 6(2), 186-202.

Kasmad, R., Alwi, \& Tamba, L. (2018). Discretion Dilemma of Street-Level Bureaucracy in Implementation of the Street Vendors Empowerment Policy in Makassar City, Indonesia. American Journal of Humanities and Social Sciences Research (AJHSSR), 2(8), 106-115.

Kasmad, R., Samboteng, L., \& Mahsyar, A. (2019). The Unwise Policy Of Community Based-Organisation: Can It Empower Them? Implementation Network Of Food Diversification In Indonesia. OPCION, 35(22), 2899-2921.

Lin, Y., \& Wu, L. Y. (2014). Exploring the role of dynamic capabilities in firm performance under the resource-based view framework. Journal of Business Research, 67(3), 407-413. https://doi.org/10.1016/j.jbusres.2012.12.019

Lukman Samboteng. (2020). Talent management of state civil officers ( ASN ), bureaucratic digitalization era in Indonesia. 41(31), 157-169.

Mikalef, P., \& Pateli, A. (2017). Information technology-enabled dynamic capabilities and their indirect effect on competitive performance: Findings from PLS-SEM and fsQCA. Journal of Business Research, 70,1-16. https://doi.org/10.1016/j.jbusres.2016.09.004

Najrani, M. (2016). The effect of change capability, learning capability and shared leadership on organizational agility. Pepperdine University Graduate, 138.

O’Connor, R. E., Bord, R. J., Fisher, A., von Glasenapp, M., Thornton, T. F., Ledogar, R. J., Fleming, J., Schosinsky, G., Birkmann, J. J., De Aranzabal, I., Schmitz, M. F., Aguilera, P., Pineda, F. D., Cutter, S. L., Boruff, B. J., Shirley, W. L., Bonilla-moheno, M., Redo, D. J., Aide, T. M., ... Tapia, W. (2014). El papel de las instituciones informales en el uso de los recursos forestales en Am\{é\}rica Latina. Global Environmental Change. https://doi.org/10.1016/j.foreco.2011.03.036

Peach, Dr Deborah, D. J. M. (2011). Work Integrated Learning for Life : Encouraging Agentic Engagement. July, 4-7.

Roberts, N., \& Grover, V. (2012). Investigating firm's customer agility and firm performance: The importance of aligning sense and respond capabilities. Journal of Business Research, 65(5), 579585. https://doi.org/10.1016/j.jbusres.2011.02.009

Rueda-Manzanares, A., Aragón-Correa, J. A., \& Sharma, S. (2008). The influence of stakeholders on the environmental strategy of service firms: The moderating effects of complexity, uncertainty and munificence. British Journal of Management, 19(2), 185-203. https://doi.org/10.1111/j.14678551.2007.00538.x

Rulinawaty, Arifin, S., \& Samboteng, L. (2020). LEADING AGILE ORGANIZATION Can Indonesian Bureaucracy become agile? International Research Association for Talent Development and Exellence, 12(1).

Rulinawaty, Samboteng, L., Arifin, S., \& HAsanuddin. (2020). CRAFTING AGILE BUREAUCRACY: Transforming Work Ethic of Civil Servant and Organization Culture Bureaucracy in Indonesia. International Journal of Innovation, Creativity and Change.

Sena, J. A. E. O. (2012). Microsoft vs Apple: Which is Great by Choice? Journal of Information System Applied Research, 5(3), 1-23.

Srivastava, M., Moser, R., \& Hartmann, E. (2018). The networking behavior of Indian executives under environmental uncertainty abroad: An exploratory analysis. Journal of Business Research, 82(September 2016), 230-245. https://doi.org/10.1016/j.jbusres.2017.09.036

Stirling, A. (2008). "Opening up" and "closing down": Power, participation, and pluralism in the social appraisal of technology. Science Technology and Human Values. https://doi.org/10.1177/0162243907311265

Swafford, P. M., Ghosh, S., \& Murthy, N. (2008). Achieving supply chain agility through IT integration and flexibility. International Journal of Production Economics, 116(2), 288-297. https://doi.org/10.1016/j.ijpe.2008.09.002

Tiernan, A. (2015). The dilemmas of organisational capacity. Policy and Society, 34(3-4), 209-217. https://doi.org/10.1016/j.polsoc.2015.09.004

Williams, C. L., Muller, C., \& Kilanski, K. (2012). Gendered Organizations in the New Economy. Gender and Society, 26(4), 549-573. https://doi.org/10.1177/0891243212445466 